\title{
Changing Students' Conceptions of Newton's Second Law through Express-Refute-Investigate-Clarify (ERIC) Text
}

\author{
Nuzulira Janeusse Fratiwi ${ }^{1, *}$, Achmad Samsudin ${ }^{1}$, Taufik Ramlan Ramalis ${ }^{1}$, Bayram Costu ${ }^{2}$ \\ ${ }^{1}$ Department of Physics Education, Universitas Pendidikan Indonesia, Indonesia \\ ${ }^{2}$ Department of Science Education, Yildiz Technical University, Turkey
}

Received March 6, 2020; Revised April 27, 2020; Accepted May 13, 2020

Copyright $@ 2020$ by authors, all rights reserved. Authors agree that this article remains permanently open access under the terms of the Creative Commons Attribution License 4.0 International License

\begin{abstract}
The aim of this research was to change students' conceptions of Newton's Second Law (NSL) through Express-Refute-Investigate-Clarify (ERIC) text. Students' alternative conception can be a problem to learn other physics concepts, especially on basic concepts such as acceleration, force and mass on Newton's Second Law. The research method was used mixed methods, with an embedded mixed method as a research design. The participant involved in this research were 31 students (15 boys and 16 girls, their age were 15-16 years old) at one of the senior high schools in Sukabumi, West Java, Indonesia. Data were collected through Multi-representation Of Tier Instrument On Newton's law (MOTION) as much as six questions in the form of a four-tier test. Students' conceptions were analyzed using the rubric. The quantitative data were the percentage of students' conceptions, while the qualitative data were obtained based on conceptual change and students' answers in the ERIC text. From the data analysis, the average percentage of Sound Understanding (SU) was enhanced and Alternative Conception was decreased from pre-test to post-test. It can be concluded that the use of ERIC text can change students' conceptions of Newton's Second Law into a scientific concept. Teachers can use ERIC text to enhance students' conceptual understanding or reduce alternative conceptions, especially on NSL.
\end{abstract}

Keywords Express-Refute-Investigate-Clarify (ERIC) Text, Conceptual Change, Newton's Second Law (NSL)

\section{Introduction}

Alternative conception or misconception become a popular topic around researchers, including in physics education. Many kinds of research show that each student enters the classroom through a scheme of knowledge and views as an outcome of their frequent everyday practices in their daily life [1]-[6]. Subsequently, they practice concepts diverse from scientific concepts called alternative conception. Alternative conceptions occur mostly in physics concepts, such as concepts on Newton's law material. The relationship between acceleration, force and mass, as characterized in Newton's Second Law (NSL), $\Sigma \mathbf{F}$ $=$ ma , is possibly the popularly known equation in physics education [1]. Nevertheless, students remain difficult for a deep understanding of the relationship between acceleration, force and mass. Because the concept in NSL is practical in several topics of preliminary mechanics, it is crucial to be understood [1], [7]-[9].

Conventional teaching methods have not been significant as much as we were predictable on changing students' alternative conception into scientific concepts [10]-[13]. Several instructional methods have advanced based on the theory of conceptual change process [2], [14][17]. One form of the instructional materials that purpose to change students' alternative conception is refutational text or conceptual change text. Refutational texts include three main structures. Description of alternative concepts that are commonly held. Afterward, the refutational statement states that the alternative conception is mistaken. Directly then, the scientifically accepted conception is obtainable as a disparity [18]-[20].

Many kinds of research have publicized that refutational text or conceptual change texts assistance students in modification of their alternative conceptions and enhance the conceptual understanding [2], [21]-[25]. Research by Caleon \& Subramaniam [22] aims to determine the impact of the refutational text on students' alternative conceptions. The use of refutational text is combined with refutational video to present physical phenomena in periodic wave material. The results showed that the use of video-assisted refutational text was more effective than traditional texts in changing students' conceptions. Research conducted by Ozkan \& Selcuk [23] aims to determine the impact of using 
Conceptual Change Texts (CCT) assisted with technology (video) to improve students' conceptual understanding of buoyancy concepts. The results showed that the increase in students' conceptual understanding was higher by using technology assisted CCT than traditional methods. Besides, through the application of technology assisted CCT, the reduction in the percentage of students' alternative conceptions is higher than in traditional methods. Aslan \& Demircioğlu [21] investigated the effect of video-assisted conceptual change texts on 12th grade students' understanding and alternative conceptions about the gas concept. The results showed that teaching with the video-assisted conceptual change texts was more effective in overcoming students' alternative conceptions on the gas concept. Some research has completed using refutational text or conceptual change text, researchers combine text with video, without any simulation or animation - besides, the text and video not integrated with each other.

Prior research recommended that the general practice of technologies, such as simulations and virtual laboratories, has the possibility to sustenance students' investigation of scientific concepts [2], [5], [26]-[30]. Tural \& Tarakç1 [27] studied the effectiveness of physical models and simulations on students' understanding of electromagnetic induction concept. The nine samples were volunteers from the fourth year of the physics education undergraduate program at a state university in Turkey. At the conclusion, simulations had a positive effect on students to understand electromagnetic induction and its everyday life applications. Therefore, simulations or virtual laboratories can combine with refutational text. The three main structures in refutational text change into four structures by inserting investigative activities through simulations after the refutation sentence. This activity is expected to be able to visualize abstract concepts and directly involve students so that conceptual changes or reconstructing students' alterative conception can occur. The new structure of refutational text named Express-Refute-Investigate-Clarify (ERIC) text. The example of four structures of ERIC is shown in Figure 1.

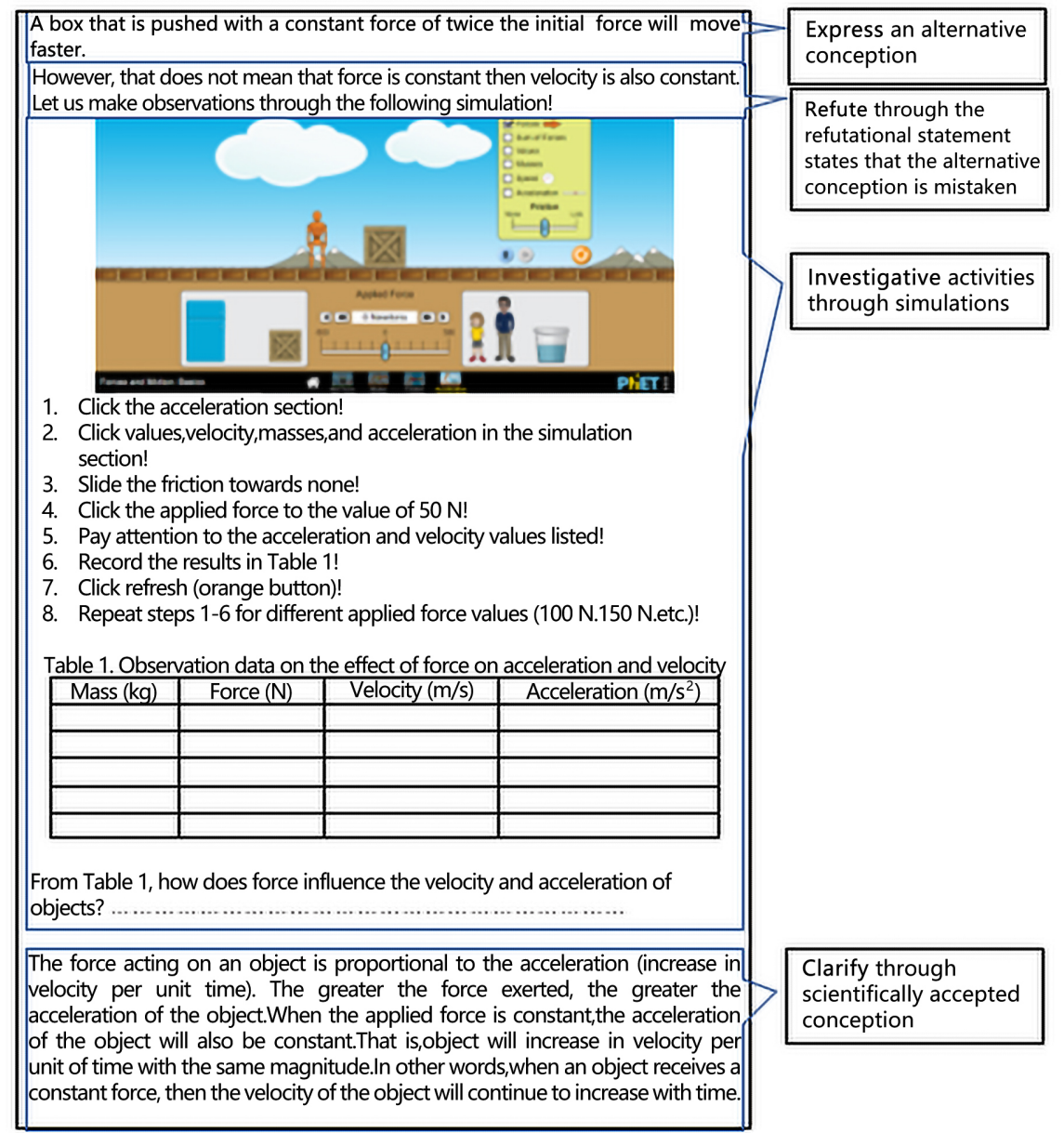

Figure 1. The Four Structure of Express-Refute-Investigate-Clarify (ERIC) Text 
Hence, the aim of this research was to change students' conceptions of Newton's Second Law (NSL) through the new structure of refutational text named Express-Refute-Investigate-Clarify (ERIC) Text.

\section{Materials and Methods}

The research method was used mixed methods (quantitative and qualitative). The use of mixed methods carried out in order to obtain better data to answer research problems. Quantitative research methods used to determine the percentage of changes students' conceptions of after the application Express-Refute-Investigate-Clarify (ERIC) text, while the qualitative method used to determine the process of students' conceptual changes and students' answer in ERIC text. The research design was embedded mixed methods. The embedded mixed methods design combines quantitative and qualitative research methods.

\subsection{Participants}

The participant in this study was one class at K-10 level at a senior high school in Sukabumi, West Java, Indonesia. The participants amount 31 students, 15 of them were boys and 16 of them were girls. The students aged an average of 15 to 16 years. They had studied NSL material in junior high school before this research. Students get a pre-test one week before treatment through ERIC text. Then, students get treatment or learning processes using ERIC text carried out for 90 minutes. One week after treatment, students get a post-test. The ERIC text used in this research will be explained in more details.

\subsection{Instrument}

The instrument in this research was named Multi-representation Of Tier Instrument On Newton's law (MOTION) in the form of a four-tier test. The instrument also uses different representations for pre- and post-test. Especially for NSL, the number of questions used are six questions (three questions for pre-test and three questions for post-test) on MOTION. Question number 1 (N1) was about the effect of force on velocity, N2 was about the effect of mass on acceleration on free fall motion and N3 was about the effect of mass on acceleration on the sloping plane. An example of MOTION for NSL shown in Figure 2.

From Figure 2, the instrument has four tiers. The first tier is the original multiple-choice, where the problem presented then the choice of answers, the second tier is the confidence rating for the first tier, the third tier is the reason for the first tier, and the fourth tier is the confidence rating for the third tier [31]-[33]. And then, through Rasch analysis, MOTION has construct validity (unidimensionality) with a value of raw variance explained by measures of $51.3 \%$ with the category "fulfilled". In addition, the instrument has also validated to three experts (one lecturer in physics education, one lecturer in physics, and one teacher of physics subject in senior high school). All NSL items are stated valid by experts. For reliability, the instrument has a Cronbach Alpha value of 0.94 with the interpretation "reliable". Therefore, the instrument is valid and reliable to use.

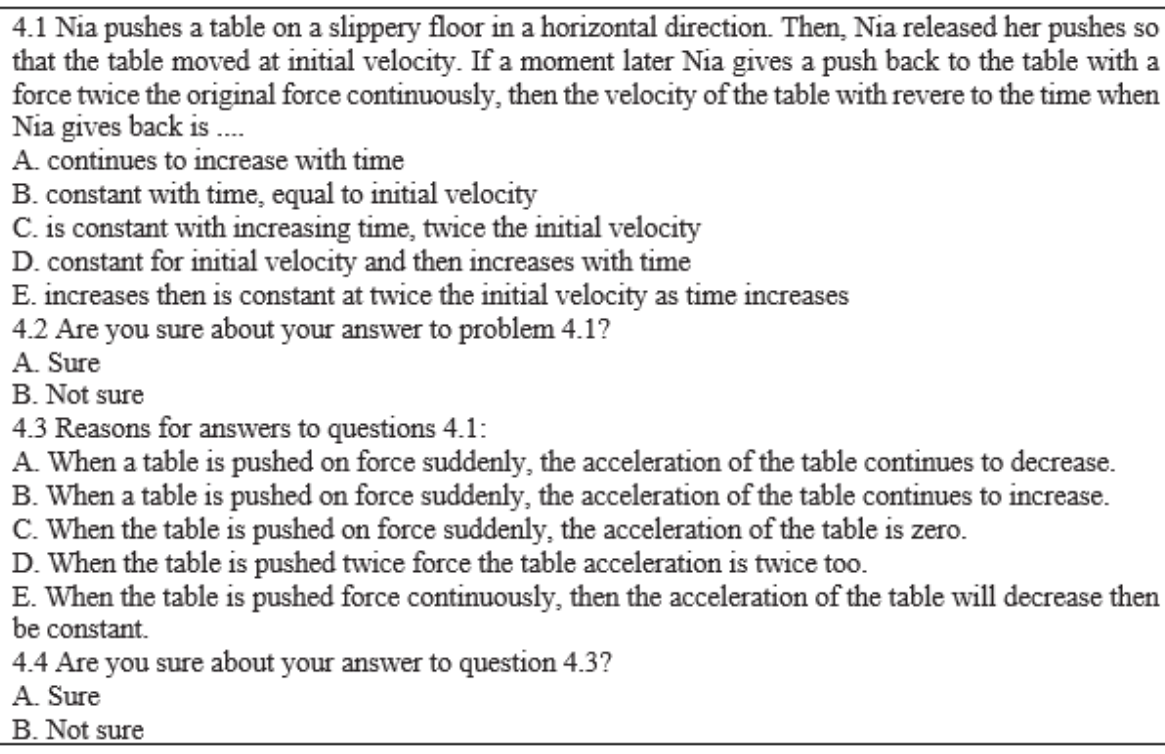

Figure 2. The Example of NSL Question on MOTION 


\subsection{Express-Refute-Investigate-Clarify (ERIC) Text}

Express-Refute-Investigate-Clarify (ERIC) text is a new structure of the refutational text. ERIC text consists of four parts, namely an express common alternative conception, refute, investigate and clarify with a scientific concept. The investigate media used are simulations and videos that can be operated by students. The simulations and videos presented in ERIC text integrated with PhET and YouTube. Besides, students can also write their answers on the ERIC text. ERIC text created based on the web (Moodle) that can be accessed through the page quiz.tioc1.com. ERIC text can be opened via a computer, laptop or mobile phone. Before using ERIC text, students need to create an account first. This account includes data on name, password, e-mail, address, class, and gender. Each student can use the data of name and password to log in to ERIC text. The ERIC text used when the teacher guides the learning process. The material on ERIC text is Newton's Second Law. This material is compiled based on the findings of students' alternative conception in preliminary studies. Newton's Second Law material is also adjusted to Indonesia's curriculum and textbook.

\subsection{Procedures for Data Analysis}

Data obtained from pre- and post-test are then analyzed based on the rubric in Table 1. Students' conceptions grouped into Sound Understanding (SU), Partial Understanding (PU), No Understanding (NU), Alternative Conception (AC) and No Coding (NC). Percentage of conception obtained from the division between the number of students on conception with the total number of students (31). Conceptual change during pre- and post-test were also analyzed. Then the changes of students' alternative conception were analyzed for each NSL problem and students' answer in ERIC text.

Table 1. The Rubric for Students' Conception Criteria and Scoring on Each Conception

\begin{tabular}{|c|c|c|c|c|c|}
\hline Conception Criteria & Symbol & Tier 1 & Tier 2 & Tier 3 & Tier 4 \\
\hline Sound Understanding (SU) & & Correct & Sure & Correct & Sure \\
\hline \multirow{11}{*}{ Partial Understanding (PU) } & & Correct & Sure & Correct & Not sure \\
\hline & & Correct & Not sure & Correct & Sure \\
\hline & & Correct & Not sure & Correct & Not sure \\
\hline & & Correct & Sure & Incorrect & Not sure \\
\hline & & Correct & Not sure & Incorrect & Sure \\
\hline & & Correct & Not sure & Incorrect & Not sure \\
\hline & & Incorrect & Sure & Correct & Not sure \\
\hline & & Incorrect & Not sure & Correct & Sure \\
\hline & & Incorrect & Not sure & Correct & Not sure \\
\hline & & Correct & Sure & Incorrect & Sure \\
\hline & & Incorrect & Sure & Correct & Sure \\
\hline \multirow{3}{*}{ No Understanding (NU) } & & Incorrect & Sure & Incorrect & Not sure \\
\hline & & Incorrect & Not sure & Incorrect & Sure \\
\hline & & Incorrect & Not sure & Incorrect & Not sure \\
\hline Alternative Conception (AC) & $B$ & Incorrect & Sure & Incorrect & Sure \\
\hline No Coding (NC) & $\begin{array}{l}---1 \\
1--1\end{array}$ & \multicolumn{4}{|c|}{ If not filling one or more items (tier) } \\
\hline
\end{tabular}


Table 2. The Percentage of Students' Conceptions During Pre- and Post-test

\begin{tabular}{|c|c|c|c|c|c|c|c|c|c|c|}
\hline \multirow[t]{2}{*}{ No. } & \multicolumn{2}{|c|}{$\begin{array}{l}\text { Sound Understanding } \\
\text { (SU) }\end{array}$} & \multicolumn{2}{|c|}{ Partial Understanding (PU) } & \multicolumn{2}{|c|}{$\begin{array}{l}\text { No Understanding } \\
(\mathrm{NU})\end{array}$} & \multicolumn{2}{|c|}{ Alternative Conception (AC) } & \multicolumn{2}{|c|}{ No Coding (NC) } \\
\hline & Pre- & Post- & Pre- & Post- & Pre- & Post- & Pre- & Post- & Pre- & Post- \\
\hline N1 & - & $\begin{array}{l}\mathrm{S} 14, \mathrm{~S} 20, \\
\mathrm{~S} 21, \mathrm{~S} 23, \\
\mathrm{~S} 25 \underline{\mathbf{( 1 6 \% )}}\end{array}$ & $\begin{array}{l}\text { S02, S05, } \\
\text { S07, S10, } \\
\text { S11, S12, } \\
\text { S14, S15, } \\
\text { S16, S17, } \\
\text { S18, S19, } \\
\text { S20, S23, } \\
\text { S31 (48\%) }\end{array}$ & $\begin{array}{l}\text { S01, S02, } \\
\text { S03, S05, } \\
\text { S06, S08, } \\
\text { S10, S11, } \\
\text { S12, S13, } \\
\text { S22, S24, } \\
\text { S29, S31 } \\
(\mathbf{4 5 \% )}\end{array}$ & $\begin{array}{l}\text { S01, } \\
\text { S03, } \\
\text { S13, } \\
\text { S27, S30 } \\
\underline{\mathbf{( 1 6 \% )}}\end{array}$ & $\begin{array}{l}\mathrm{S} 30 \\
\mathbf{( 3 \% )} \\
\end{array}$ & $\begin{array}{l}\text { S04, S06, } \\
\text { S08, S22, } \\
\text { S24, S25, } \\
\text { S26, S28, S29 } \\
(\mathbf{2 9 \% )}\end{array}$ & $\begin{array}{l}\text { S04, S07, } \\
\text { S15, S16, } \\
\text { S17, S18, } \\
\text { S19, S26, } \\
\text { S27 (29\%) }\end{array}$ & $\begin{array}{l}\text { S09, } \\
\text { S21 } \\
(\mathbf{7 \% )} \\
\end{array}$ & $\begin{array}{l}\text { S09, } \\
\text { S28 } \\
(\mathbf{7 \% )} \\
\end{array}$ \\
\hline $\mathrm{N} 2$ & $\begin{array}{l}\mathrm{S} 18 \\
\mathbf{( 3 \% )} \\
\end{array}$ & $\begin{array}{l}\text { S02, S05, } \\
\text { S07, S08, } \\
\text { S10, S } 11, \\
\text { S12, S16, } \\
\text { S18, S19, } \\
\text { S20, S22, } \\
\text { S23, S24, } \\
\text { S27, S29, } \\
\text { S30, S } 31 \\
\underline{(58 \%)}\end{array}$ & $\begin{array}{l}\text { S01, S09, } \\
\text { S20, S23, } \\
\text { S26 (16\%) }\end{array}$ & $\begin{array}{l}\text { S01, S06, } \\
\text { S14, S21, } \\
\text { S25 (16\%) }\end{array}$ & $\begin{array}{l}\text { S03, } \\
\text { S04, S30 } \\
(\mathbf{1 0 \% )}\end{array}$ & - & $\begin{array}{l}\text { S02, S05, } \\
\text { S06, S07, } \\
\text { S08, S10, } \\
\text { S11, S12, } \\
\text { S14, S15, } \\
\text { S16, S17, } \\
\text { S19, S21, } \\
\text { S22, S24, } \\
\text { S25, S27, } \\
\text { S28, S29, S31 } \\
(\mathbf{6 8 \% )} \\
\end{array}$ & $\begin{array}{l}\text { S03, S13, } \\
\text { S15, S17, } \\
\text { S26, S28 } \\
(\mathbf{1 9 \% )}\end{array}$ & $\begin{array}{l}\mathrm{S} 13 \\
(\mathbf{3 \%}) \\
\end{array}$ & $\begin{array}{l}\text { S04, } \\
\text { S09 } \\
(\mathbf{7 \% )} \\
\end{array}$ \\
\hline N3 & $\begin{array}{r}\mathrm{S} 22 \\
\mathbf{( 3 \% )} \\
\end{array}$ & $\begin{array}{l}\text { S02, S10, } \\
\text { S14, S19, } \\
\text { S20, S23, } \\
\text { S24, S25 } \\
\underline{(\mathbf{2 6 \%})}\end{array}$ & $\begin{array}{l}\text { S04, S06, } \\
\text { S08, S09, } \\
\text { S10, S14, } \\
\text { S24, S29, } \\
\text { S30 } \underline{\mathbf{( 2 9 \% )}}\end{array}$ & $\begin{array}{l}\text { S04, S08, } \\
\text { S11, S13, } \\
\text { S15, S17, } \\
\text { S22, S27, } \\
\text { S29, S30, } \\
\text { S31 (35\%) }\end{array}$ & $\begin{array}{l}\text { S01, } \\
\text { S02, } \\
\text { S03, } \\
\text { S13, } \\
\text { S19, } \\
\text { S20, S31 } \\
\underline{(23 \%)} \\
\end{array}$ & - & $\begin{array}{l}\text { S07, S11, } \\
\text { S12, S15, } \\
\text { S16, S17, } \\
\text { S18, S21, } \\
\text { S23, S25, } \\
\text { S26, S27, S28 } \\
(\mathbf{4 2 \% )} \\
\end{array}$ & $\begin{array}{l}\text { S01, S03, } \\
\text { S05, S06, } \\
\text { S07, S09, } \\
\text { S12, S16, } \\
\text { S18, S21, } \\
\text { S26, S28 } \\
(\mathbf{3 9 \% )} \\
\end{array}$ & $\begin{array}{l}\text { S05 } \\
(\mathbf{3 \%}) \\
\end{array}$ & - \\
\hline Average & $2 \%$ & $34 \%$ & $31 \%$ & $32 \%$ & $16 \%$ & $1 \%$ & $46 \%$ & $29 \%$ & $4 \%$ & $5 \%$ \\
\hline
\end{tabular}

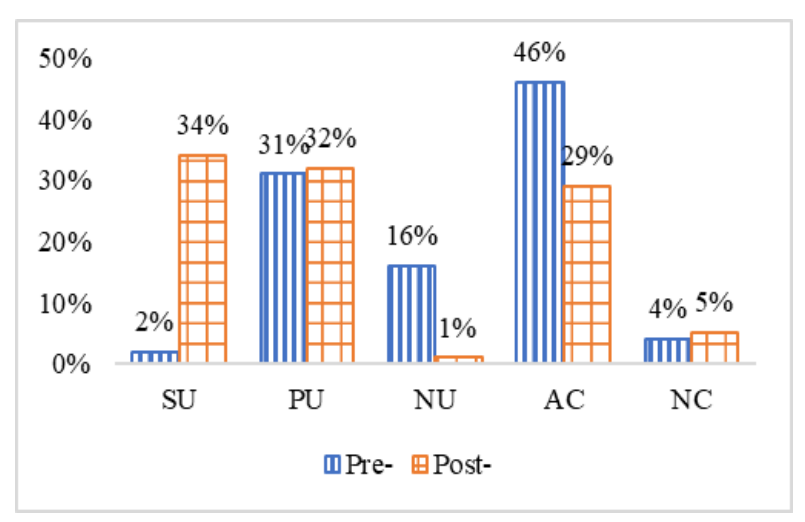

Figure 3. The Average Percentage of Students' Conceptions during Preand Post-test

\section{Result and Discussion}

In the results and discussion section, the results of students' conceptions are presented during the pre- and post-test. Furthermore, changes in each conception are also analyzed. Finally, the students' answers on ERIC text are also analyzed. The students' conceptions during the preand post-test are shown in Table 2.

Based on Table 2, distribution of students was obtained for each conception at pre- and post-test, also for each number of questions. Based on the percentage of each conception, there are changes from pre- and post-test. For more details, the average percentage of students' conceptions during pre- and post-test is shown in Figure 3.

The average percentage of Sound Understanding (SU), Partial Understanding (PU) and No Coding (NC) increases from pre-test to post-test, while the average percentage of No Understanding (NU) and Alternative Conception (AC) decreases from pre-test to post-test.

To obtain information about conception construction after the learning process with ERIC text, we explain changes in students' conceptions during pre- and post-test. Changes in the percentage of students' conceptions from pre-test to post-test are shown in Table 3. 
Table 3. Change of Percentage of Students' Conception from Pre-test to Post-test

\begin{tabular}{|c|c|c|c|c|c|c|c|c|c|c|}
\hline \multirow[t]{2}{*}{ No. } & \multicolumn{2}{|c|}{ SU } & \multicolumn{2}{|c|}{ PU } & \multicolumn{2}{|c|}{$\mathrm{NU}$} & \multicolumn{2}{|c|}{ 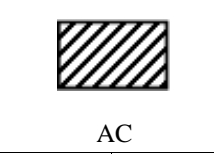 } & \multicolumn{2}{|c|}{$\begin{array}{c}---\mid \\
\mathrm{NC}\end{array}$} \\
\hline & $\mathrm{C}(\%)$ & $\mathrm{TC}$ & $\mathrm{C}(\%)$ & $\mathrm{TC}$ & $\mathrm{C}(\%)$ & $\mathrm{TC}$ & $\mathrm{C}(\%)$ & $\mathrm{TC}$ & $\mathrm{C}(\%)$ & $\mathrm{TC}$ \\
\hline $\mathrm{N} 1$ & +16 & PoC & -3 & $\mathrm{NeC}$ & +13 & $\mathrm{PoC}$ & 0 & $\mathrm{NoC}$ & 0 & $\mathrm{NoC}$ \\
\hline $\mathrm{N} 2$ & +55 & $\mathrm{PoC}$ & 0 & $\mathrm{NoC}$ & +10 & PoC & +49 & $\mathrm{PoC}$ & -4 & $\mathrm{NeC}$ \\
\hline N3 & +23 & PoC & +6 & $\mathrm{PoC}$ & +23 & $\mathrm{PoC}$ & +3 & $\mathrm{PoC}$ & +3 & $\mathrm{PoC}$ \\
\hline Average & +32 & PoC & +1 & PoC & +15 & PoC & +17 & $\mathrm{PoC}$ & -1 & $\mathrm{NeC}$ \\
\hline
\end{tabular}

Info: $\mathrm{N}=$ Question Number, $\mathrm{C}=$ Percentage Change, $\mathrm{TC}=$ Type of Change, $\mathrm{PoC}=$ Positive Change, $\mathrm{NeC}=$ Negative Change, NoC $=$ No Change

Table 4. Distribution of Students for Each Category of Conception Change in Pre- and Post-test

\begin{tabular}{|c|c|c|c|c|}
\hline Conceptual Change Category & Pre- & $\rightarrow$ & Post- & Students \\
\hline \multirow{5}{*}{ Acceptable Change (ACh) } & 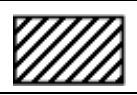 & $\rightarrow$ & & S25 \\
\hline & $B$ & $\rightarrow$ & & S06, S08, S22, S24, S29 \\
\hline & & $\rightarrow$ & & $\mathrm{S} 01, \mathrm{~S} 03, \mathrm{~S} 13$ \\
\hline & $\begin{array}{l}--1 \\
-1\end{array}$ & $\rightarrow$ & & $\mathrm{S} 21$ \\
\hline & & $\rightarrow$ & & $\mathrm{S} 14, \mathrm{~S} 20, \mathrm{~S} 23$ \\
\hline \multirow{3}{*}{ No Acceptable (NAc) } & & $\rightarrow$ & $B$ & S27 \\
\hline & BD & $\rightarrow$ & $\begin{array}{l}--1 \\
1--\rfloor\end{array}$ & S28 \\
\hline & & $\rightarrow$ & $B$ & S07, S15, S16, S17, S18, S19 \\
\hline \multirow{4}{*}{ No Change (NCh) } & & $\rightarrow$ & & $\mathrm{S} 02, \mathrm{~S} 05, \mathrm{~S} 10, \mathrm{~S} 11, \mathrm{~S} 12, \mathrm{~S} 31$ \\
\hline & & $\rightarrow$ & & $\mathrm{S} 30$ \\
\hline & BD & $\rightarrow$ & BD & S04, S26 \\
\hline & {$\left[\begin{array}{l}--- \\
-1\end{array}\right.$} & $\rightarrow$ & {$\left[\begin{array}{l}--- \\
-1\end{array}\right.$} & S09 \\
\hline
\end{tabular}

Based on Table 3, there is a positive change $(\mathrm{PoC})$ for all questions in the SU. For PU, N1 has a negative change (NeC), N2 has not changed (NoC), and N3 has a positive change, but overall, it has positive changes. For NU, there are positive changes for all questions. For NC, there are positive changes for $\mathrm{N} 3$, negative changes for $\mathrm{N} 2$, and no change for N1. For AC, there are positive changes for N2 and $\mathrm{N} 3$, but they do not change for N1. The highest alternative conception reconstruction occurs in N2, namely the concept of mass influence on acceleration. At pre-test, most students assumed that objects that had a greater mass would fall first. However, after the use of ERIC text, an alternative conception reconstruction took place. This is consistent with Ferreira et al. [1] that students do not understand the formulation of NSL. In addition, Liu \& Fang [34] and Poutot \& Blandin [35] also found that students assumed that objects with greater mass would fall the fastest. Then, an example of an analysis of changes in students' conceptions for question number 1 (N1) is shown in Table 4.

Based on Table 4, the greatest total changes occurred in the Acceptable Change (ACh) category of 13 students. In the ACh category, the change from AC to PU was the most common change. That is, the implementation of Refutational Text Interactive (RT) occurs in the construction of students' conceptions. However, the construction that occurred was still in the Partial Understanding (PU) category. In the No Acceptable (NAc) category, the most changes occurred from PU to AC, namely S07, S15, S16, S17, S18 and S19. Whereas in the No Change ( $\mathrm{NCh}$ ) category the most occurred in PU as many as six students. 
The concept in N1 is the effect of force on velocity, i.e. in the event of objects being pushed with a fixed force twice the initial force. At the pre-test, S07, S16, and S19 said that when an object is given a fixed force twice the initial force, the object will move at the same velocity as the initial velocity and then increase with time because the acceleration of the object also becomes twice initial acceleration. The answers of S07, S16, and S19 are wrong, but the reasons are correct, and they are sure about the answers and the reasons so they are categorized as Partial Understanding (PU). At post-test, S07 said that when an object is given a fixed force of twice the initial force, the velocity will remain with increasing time because the acceleration of the object is zero. Whereas S16 says that when an object is given a constant force of twice the initial force the velocity will remain at twice the initial velocity because the acceleration of the object will continue to decrease. S19 says that when an object is given a constant force twice the original force, the velocity will remain and then increase because the acceleration also increases. The answers and reasons of S07, S16, and S19 are wrong and they are sure about the answers and reasons so they have an alternative conception.

At the pre-test, S15, S17, and S18 said that when an object is given a constant force of twice the original force, then the object will move at a velocity that continues to increase with increasing time. S15 gives a reason because the acceleration of the object will decrease then constantly. S17 and S18 say that the acceleration of objects will also continue to increase. The answers of S15, S17, and S18 are correct, but the reasons are wrong, and sure with answer and reason, so they are categorized as Partial Understanding (PU). At the post-test, S15 said that when an object is given a constant force of twice the initial force, the velocity will increase and then be constant because the acceleration decreases. S18 also says that when an object is given a constant force of twice the initial force, the velocity will increase and then be constant because the acceleration is zero. Whereas S17 says that when objects are given a constant force of twice the initial force, the velocity of objects is constant and then increasing because the acceleration of objects continues to increase. The answers and reasons of S15, S17, and S18 are wrong and they are sure about answers and reasons, so they have an alternative conception.

S15 tends to sustain the reason given that force will cause the acceleration of the object to decrease. When S15 and S16 fill in observational data on ERIC text, S15 and $\mathrm{S} 16$ fill in correctly about the relationship between force, velocity, and acceleration. However, in the explaining, S15 and S16 cannot correctly explain the relationship of forces, velocity, and acceleration of the observational data. The answers of S15 and S16 are the same "velocity and acceleration do not affect the force but the mass of the object". This can be one of the causes of alternative conceptions in S15 and S16.

$\mathrm{S} 17$ tends to preserve that when the velocity continues to increase the acceleration of objects it also continues to increase. In addition, S19 and S27 also tend to maintain that when an object is given a constant force of twice the initial force, the velocity will remain then increase. But at the post-test, S19 and S27 said the velocity increased because the acceleration also increased. Students are still confused in distinguishing between velocity and acceleration [35]. In addition, Liu \& Fang [34] said that students assume that when the velocity is greater or smaller, then the acceleration will also be greater or smaller. When filling ERIC text, S18 does not properly observe. Therefore, S18 also cannot properly explain the relationship between force, velocity, and acceleration. Incorrect observations and explanations made by S18 can lead to alternative conceptions.

An alternative conception in N1 can also occur because the post-test is presented in the form of a figure in the form of a graph of velocity to time and acceleration to time. This is in accordance with Planinic, Milin-Sipus, Katic, Susac, \& Ivanjek [36] that students find it difficult to understand graphs in the context of physics, especially on kinematics.

This is accordance with some research [37]-[39] that alternative conceptions are difficult to change and require a long process if this conception is already firmly attached to students' thinking.

\section{Conclusions}

Based on the research results, the use of ERIC text can change students' conceptions on Sound Understanding (SU) and reduce students' alternative conceptions. Besides, ERIC text can also qualitatively analyze the answers of students who have the potential to have an alternative conception. The teacher can use ERIC text to enhance students' conceptual understanding and reduce students' alternative conceptions, especially on Newton Second Law. ERIC text can be used through computers, laptops, or mobile phones. The use of ERIC text can visualize abstract concepts through videos and simulations. However, teachers must also pay attention to the initial process before using ERIC text, which is the student registration process because not all students can do it. In addition, ERIC text is web-based so that available internet connections also need attention.

\section{REFERENCES}

[1] A. Ferreira, M. Lemmer, and R. Gunstone, "Alternative Conceptions: Turning Adversity into Advantage," Res. Sci. Educ., vol. 49, no. 3, pp. 657-678, 2017.

[2] A. Yumuşak, I. Maraş, and M. Şahin, "Effects of computer-assisted instruction with conceptual change texts on removing the misconceptions of radioactivity," J. Educ. Gift. Young Sci., vol. 3, no. 2, pp. 23-50, 2015.

[3] N. Yürük and P. Eroğlu, "The effect of conceptual change texts enriched with metaconceptual processes on pre-service 
science teachers' conceptual understanding of heat and temperature," J. Balt. Sci. Educ., vol. 15, no. 6, pp. 693-705, 2016.

[4] M. John, J. M. Molepo, and M. Chirwa, "How Do Learners Conceptualize Plane Mirror Reflection? A Case Study of Grade 11 South African Learners," Int. J. Educ. Sci., vol. 13, no. 2, pp. 221-230, 2016.

[5] N. J. Fratiwi et al., "Overcoming Senior High School Students' Misconceptions on Newton's Laws: A DSLM with Inquiry Learning based Computer Simulations," $J$. Phys. Conf. Ser., vol. 1204, no. 1, pp. 1-8, 2019.

[6] M. Akif Haşiloğlu and S. Eminoğlu, "Identifying Cell-related Misconceptions among Fifth Graders and Removing Misconceptions Using a Microscope," Univers. J. Educ. Res., vol. 5, no. 12B, pp. 42-50, 2017.

[7] S. Syuhendri, "A learning process based on conceptual change approach to foster conceptual change in newtonian mechanics," J. Balt. Sci. Educ., vol. 16, no. 2, pp. 228-240, 2017.

[8] Y. H. Chien and P. Y. Chu, "The Different Learning Outcomes of High School and College Students on a 3D-Printing STEAM Engineering Design Curriculum," Int. J. Sci. Math. Educ., vol. 16, pp. 1047-1064, 2018.

[9] A. Zulfikar et al., "Reducing Eleventh-Grade Students' Misconceptions on Gravity Concept using PDEODE*E-Based Conceptual Change Model," J. Phys. Conf. Ser., vol. 1204, no. 1, 2019.

[10] T. Jiang, S. Wang, J. Wang, and Y. Ma, "Effect of different instructional methods on students' conceptual change regarding electrical resistance as viewed from a synthesized theoretical framework," Eurasia J. Math. Sci. Technol. Educ., vol. 14, no. 7, pp. 2771-2786, 2018.

[11] K. A. Cheek, "Students' Understanding of Large Numbers as A Key Factor in Their Understanding of Geologic Time," Int. J. Sci. Math. Educ., vol. 10, pp. 1047-1069, 2012.

[12] F. Kayima and S. T. Mkimbili, "How Do Chemistry Teachers Deal with Students' Incorrect/Undesired Responses to Oral Classroom Questions? Exploring Effective Feedback Practices," Res. Sci. Educ., 2019.

[13] A. Samsudin, A. Suhandi, D. Rusdiana, I. Kaniawati, and B. Coştu, "Investigating the effectiveness of an active learning based-interactive conceptual instruction (ALBICI) on electric field concept," Asia-Pacific Forum Sci. Learn. Teach., vol. 17, no. 1, pp. 1-41, 2016.

[14] B. Gregorcic and J. Haglund, "Conceptual Blending as an Interpretive Lens for Student Engagement with Technology: Exploring Celestial Motion on an Interactive Whiteboard," Res. Sci. Educ., 2018.

[15] S. Olitsky, "Facilitating changes in college teaching practices: Instructional reform, identity conflict and professional community in a K-20 partnership," Res. Sci. Educ., vol. 45, pp. 625-646, 2015.

[16] H. jeong Kim, M. Metzger, and R. M. Heaton, "Teacher Planning Sessions as Professional Opportunities to Learn: an Elementary Mathematics Teacher's Re-conceptualization of Instructional Triangles," Int. J. Sci. Math. Educ., 2019.

[17] A. Samsudin et al., "Analyzing the students' conceptual change on kinetic theory of gases as a learning effect though computer simulations-assisted conceptual change model," Univers. J. Educ. Res., vol. 8, no. 2, pp. 425-437, 2020.
[18] J. L. G. Braasch, S. R. Goldman, and J. Wiley, "Influences of text and reader characteristics on learning from refutations in science texts," J. Educ. Psychol., vol. 105, no. 3, pp. 561$578,2013$.

[19] L. Mason, S. Zaccoletti, B. Carretti, S. Scrimin, and I. A. N. Diakidoy, "The Role of Inhibition in Conceptual Learning from Refutation and Standard Expository Texts," Int. J. Sci. Math. Educ., vol. 17, no. 3, pp. 483-501, 2019.

[20] C. D. Tippett, "Refutation Text In Science Education: A Review Of Two Decades Of Research," Int. J. Sci. Math. Educ., vol. 8, no. 6, pp. 951-970, 2010.

[21] A. Aslan and G. Demircioğlu, "The Effect of Video-assisted Conceptual Change Texts on 12 th Grade Students' Alternative Conceptions: The Gas Concept," Procedia - Soc. Behav. Sci., vol. 116, pp. 3115-3119, 2014.

[22] I. Caleon and R. Subramaniam, "Addressing students' alternative conceptions on the propagation of periodic waves using a refutational text," Phys. Educ., vol. 48, no. 5, pp. 657-663, 2013.

[23] G. Ozkan and G. S. Selcuk, "Effect of Technology Enhanced Conceptual Change Texts on Students' Understanding of Buoyant Force," Univers. J. Educ. Res., vol. 3, no. 12, pp. 981-988, 2015.

[24] A. Suhandi, A. Samsudin, E. Suhendi, N. Hermita, and E. N. Syamsiah, "Facilitating Conceptual Changes of High School Students regarding Concepts in Static Electricity and DC Circuits through the Use of VMSCDCCText," Univers. J. Educ. Res., vol. 8, no. 3, pp. 815-822, 2020.

[25] B. Çayc1, "The impacts of conceptual change text-based concept teaching on various variables," Univers. J. Educ. Res., vol. 6, no. 11, pp. 2543-2551, 2018.

[26] J. Y. Wang, H. K. Wu, S. P. Chien, F. W. Hwang, and Y. S. Hsu, "Designing applications for physics learning: Facilitating high school students' conceptual understanding by using tablet pcs," J. Educ. Comput. Res., vol. 51, no. 4, pp. $441-458,2015$.

[27] G. Tural and D. Tarakçı, "Effects of physical models and simulations to understand daily life applications of electromagnetic induction," Res. Sci. Technol. Educ., vol. 35 , no. 3, pp. 292-307, 2017.

[28] F. C. Wibowo et al., "Effectiveness of Dry Cell Microscopic Simulation (DCMS) to Promote Conceptual Understanding about Battery," in Journal of Physics: Conference Series, 2017, vol. 877 , no. 1 , pp. $1-10$

[29] N. J. Fratiwi, A. Samsudin, and B. Costu, "Enhancing K-10 students' conceptions through computer simulations-aided PDEODE*E (CS-PDEODE*E) on Newton's Laws," $J$. Pendidik. IPA Indones., vol. 7, no. 2, pp. 214-223, 2018.

[30] F. C. Wibowo, A. Setiawan, U. Alizkan, D. R. Darman, and E. Budi, "Educational technology of virtual physics laboratory (VPL) for the microscopic concept," Univers. $J$. Educ. Res., vol. 7, no. 12, pp. 2867-2882, 2019.

[31] D. Kaltakci-Gurel, A. Eryilmaz, and L. C. McDermott, "Development and application of a four-tier test to assess pre-service physics teachers' misconceptions about geometrical optics," Res. Sci. Technol. Educ., vol. 35, no. 2, pp. 238-260, 2017.

[32] I. Kaniawati, N. J. Fratiwi, A. Danawan, I. Suyana, A. Samsudin, and E. Suhendi, "Analyzing students' misconceptions about Newton's laws through four-tier 
Newtonian test ( FTNT )," J. Turkish Sci. Educ., vol. 16, no. 1, pp. 110-122, 2019.

[33] N. J. Fratiwi, I. Kaniawati, E. Suhendi, I. Suyana, and A. Samsudin, "The transformation of two-tier test into four-tier test on Newton's laws concepts," AIP Conf. Proc., vol. 1848, no. October, 2017.

[34] G. Liu and N. Fang, "Student misconceptions about force and acceleration in physics and engineering mechanics education," Int. J. Eng. Educ., vol. 32, no. 1, pp. 19-29, 2016.

[35] G. Poutot and B. Blandin, "Exploration of Students' Misconceptions in Mechanics using the FCI," Am. J. Educ. Res., vol. 3, no. 2, pp. 116-120, 2015.

[36] M. Planinic, Z. Milin-Sipus, H. Katic, A. Susac, and L.
Ivanjek, "Comparison of student understanding of line graph slope in physics and mathematics," Int. J. Sci. Math. Educ., vol. 10, pp. 1393-1414, 2012.

[37] A. Samsudin et al., "Unveiling students' misconceptions through computer simulation-based PDEODE learning strategy on dynamic electricity," in Journal of Physics: Conference Series, 2019, vol. 1280, no. 5, pp. 1-8.

[38] A. Samsudin et al., "Alleviating Students' Misconceptions About Newton's First Law Through Comparing Pdeode*e Tasks and Poe Tasks: Which is More Effective?," Turkish Online J. Educ. Technol., no. Special Issue for INTE 2017, pp. 215-221, 2017.

[39] K. K. Will, A. Masad, H. A. Vlach, and P. Kendeou, "The effects of refutation texts on generating explanations," Learn. Individ. Differ., vol. 69, pp. 108-115, 2019. 